\title{
O ESPAÇO FLUÍDO NO IMAGINÁRIO DAS ARTES CONTEMPORÂNEAS: A SENSIBILIDADE EMERGENTE ${ }^{1}$
}

\section{THE SPACE FLUID IN THE IMAGINARY OF CONTEMPORARY ARTS: EMERGING SENSITIVITY}

\author{
Valéria Cristina Pereira da Silva ${ }^{2}$ \\ Universidade Federal de Goiás, Goiânia, Brasil
}

\begin{abstract}
Resumo: As artes são, a priori, fontes privilegiadas de acesso à cultura e ao imaginário social. A partir delas, o espaço e o tempo descortinam-se como referências nas quais emergem saberes, a percepção, as astúcias, angústias, questionamentos e alternativas poético-simbólicas do momento. As artes pinçam o zeitgeist - o espírito de época - a mentalidade do período e seu universo de sentido. O que há nele de secreto e invisível ganha evidência. Desse modo, a arte põe a ver, a sentir, pensar e a imaginar. Neste artigo pretendo abordar fenomenologicamente obras de artes visuais que trazem $o$ imaginário da fluidez e os sentidos perceptivos como um sintoma do espaço-tempo em que vivemos e suas implicações. A partir do recorte das obras de Tom Storm, Cao Guimaraes, Ernesto Neto, Laura Vinci, Vinícius de Souza Almeida, Neli Azevedo, Adriana Giora, Li Hongbo e a exposição "Olfatória: O cheiro na Arte" na X Bienal do Mercosul busco identificar como as formas do sensível são postas em ação e como as imagens da fluidez desdobram-se em lugar e paisagem.
\end{abstract}

Palavras-chave: Arte; fluidez; sensibilidade; lugar; paisagem.

Abstract: Art is, a priori, privileged access source for the culture and the social imaginary. Since it's, space and time pull aside itself as references where rises knowledge, perception, wittiness, heartache, questionings and the moment poeticalsymbolic alternatives. Art absorbs the zeitgeist - an epoch spirit - the period mentality and her senses universe. What's in it as secret and invisible sticks out. In this way, art can give opportunity to see, feel, think and imagine. In this article, I pretend approach phenomenologically the visual artwork what have a fluidity imaginary and perceptive senses in the ours epoch and space symptom and their implications. From Tom Storm, Cao Guimaraes, Errnesto Neto, Laura Vinci, Vinícius de Souza Almeida, Neli Azevedo, Adriana Giora, Li Hongbo's oeuvres and Ofatoria The smell in the art exhibit at 10th Mercosul biennial, I search identify how the sensible's forms are managed and how the fluidity images broke up in paysage and place.

Keywords: Art; fluidity; sensibility; place; paysage.

\footnotetext{
${ }^{1}$ Texto elaborado a partir das reflexões teóricas do projeto intitulado: De cidades planejadas à metrópoles contemporâneas: novas sensibilidades urbanas e transformações na paisagem com o apoio financeiro do CNPq desenvolvido junto ao GEIPaT - Grupo de Estudos de Imaginário, Paisagem e Transculturalidade - NUPEAT - Núcleo de Pesquisa em Educação Ambiental e Transdiciplinaridade - Universidade Federal de Goiás - UFG.

2 Prof. Dra. da Universidade Federal de Goiás, vinculada ao Instituto de Pesquisas Socioambientais IESA/UFG, onde desenvolve pesquisas ligadas aos temas: Imaginário da Cidade, Geografia e Literatura e Arte, Cultura, Sensibilidades Contemporâneas e Pós-modernidade. E-mail: vpcsilva@ @otmail.com.
} 


\section{INTRODUÇÃO}

A investigação sobre o espaço fluído presente nas artes contemporâneas ${ }^{3}$ permite-me interpretar os sentidos da fluidez representada nelas e como essas imagens da fluidez dialogam com o conceito de espaço, criando novos modos de concebe-lo através das categorias lugar e paisagem. Busco este imaginário da fluidez também na dobragem do nosso próprio tempo, tempo ainda inscrito na penumbra de incertezas e mal compreendido. Um tempo que curva e o faz entortando para o passado na mesma direção em que segue para o futuro, deixando a estrada aberta, informe, indisciplinada, mas com uma convicção: o fim da linearidade, o fim da unicidade. O plural, múltiplo o informe predomina no contemporâneo. As artes correspondem a uma parte fundamental do imaginário ontológico do mundo que nos cerca. É imaginação ativa e possibilidade de vislumbrar futuros alternativos, criar realidades totalmente novas e lugares ideais/desejados até mesmo do passado. Consiste num meio, num fluxo, não necessariamente linear, entre o criar, o lembrar, o perceber e o imaginar. A convergência entre vida, experiência e sensibilidade amadurece sob o nome de arte.

Entrecruza-se nesta perspectiva o espaço representado nas artes visuais contemporâneas e a marchetaria cultural que evidenciam, forjando uma geografia sensível a partir das poéticas presentes nas obras selecionadas e recortadas, em suas imagens e narrativas. A arte, analisada sob prisma do imaginário, coloca-nos questões gerais sobre a possiblidade de fornecer pistas para compreendermos melhor os sintomas desse período chamado contemporâneo e o mundo em que vivemos em suas imagens fluídas e sensíveis. Ou ainda, o universo sensível da arte é capaz de nos fornecer um método para abordagem? Nessa perspectiva não há sujeito x objeto e a partir das reflexões bachelardianas, diante da obra de arte, deparamo-nos com um método de encantamento, de deslumbramento sistemático Bachelard (1994). Pois é também um fazer poético a tentativa de buscar a significação de tais obras. Os sentidos percebem, somos tomados pelas sensações. A consciência apreende sua intenção estética e buscarlhes a significação é adentrar na linguagem conotativa e imaginária que apresentam. De

\footnotetext{
3 As primeiras reflexões sobre essa temática surgiram do desafio de apresentar o tema na mesa redonda: Estética Poética e Narrativa: entre a fluidez e a permanência nas artes No II SIGEOLITERAT Simpósio de Geografia, Literatura e Arte realizado em junho de 2013 na USP.
} 
certo modo, esse fazer semiótico consiste em participar do sonho. Concordo que podemos aplicar ao saber artístico, de modo geral, a máxima que Helps atribuiu a literatura: "Se você pretende compreender a sua própria época, leia as obras de fícção produzidas nela. As pessoas quando estão vestidas em fantasias falam sem travas na língua" (HELPS, A. 1969, apud. SEVCENKO, 1998, p. 514). A realidade contemporânea, por vezes, só se revela no prisma multifacetado da imagem, dos sentidos e na emenda do fio partido em todo símbolo. Contudo, não poderia desenvolver tal tema, evidentemente, sem estabelecer um recorte ilustrativo para tentar apresentar o modo como uma determinada ideia de fluidez e sensibilidade tem emergido. Vou tomar alguns exemplos ilustrativos nas artes visuais, selecionando obras que abordam, em suas imagens, expressões a favor da fluidez e também aquelas que evocam a percepção operando outros sentidos, além da visão. Os objetivos deste trabalho consistem em explorar os significados e os simbolismos presentes nessas poéticas e problematizar as possiblidades das relações entre geografia e arte, vislumbrando a concepção de uma Geografia da Arte na qual estética, poética e narrativa componham o espaço de sentido da obra. O exercício então será movermo-nos de fora para dentro dessas obras, encará-las como espaço, paisagem e lugar de sentido.

Também não poderia fazer essa discussão sem ancoras num campo teórico. Esse campo em plena floração será a fenomenologia da imaginação bachelardiana. Nada mais oportuno do que o pensamento do filósofo pós-moderno que unira a um só tempo o espaço e a poética, os elementos da paisagem e a arte, o lugar e o sujeito por meio da topofilia. Nunca o imaginário e o espaço tiveram numa obra um encontro tão feliz. Uma fenomenologia dinâmica que não deixa escapar a essência do nosso tempo.

A fenomenologia bachelardiana é o estudo da constituição das imagens na consciência em seu dinamismo, é a própria ontologia das imagens, a metafísica da imaginação que o filósofo investiga. Nesta perspectiva, como bem definiu Bachelard (1993, p. 131), o imaginário constitui-se das imagens da imaginação. Sua contribuição ultrapassa saberes (ciência, filosofia, arte, literatura) é de extrema atualidade no pensamento contemporâneo. Na Geografia tal contribuição, está para ser melhor compreendida, pois, Bachelard toca "sensivelmente" o espaço. O espaço, como lugar das experiências a serem colhidas. Muitas das imagens operadas fazem parte do que ele chamou de complexo de cultura formando por literatura, arte e mito, ou seja, pelas diversas formas de poesia. Esse espectro de experiências culturais serve-nos de base 
para contínuas explorações no campo do imaginário, no espaço vivido. Principalmente o imaginário do nosso tempo tão cheio de relações e referências.

O palavra, a imagem e o devaneio estão ligados na tessitura do imaginário - a verdadeira imagem, nesta perspectiva, não é aquela que se vê, mas a que se sente, com todos os sentidos - penetra na cosmologia falada até precipitação do seu significado. Trata a matéria com uma fluidez imensa, o modo como fluidifica a poesia, vendo-a como o rio da linguagem, é exemplar. O fluxo imaginário onde as palavras não apenas escorrem, mas transcorrem num ciclo infinito. Nas trilhas do imaginário bachelardiano cada elemento detém um profundo conteúdo estético: por exemplo, tudo que é evocado pelo fogo esse elemento colorido, vivo, fugaz, portador de um potencial contemplativo ou pela a água fluida, simbólica, pelas as brisas e os voos, a substancia da leveza flutuante, a própria da liberdade aérea, coagula em forma de imagem poética ou mitopoética. Dialética da fluidez e da permanência no contato com o mundo através das mãos, uma geografia sensível do mundo, onde a imaginação tateia! Numa citação de Baudelaire afirma: "quanto mais a matéria é em aparência, positiva e sólida, mais sutil e laborioso é o trabalho da imaginação" (1993, p. 2).

A tônica da filosofia bachelardiana é bem sonhar, nesta perspectiva, não é a percepção das imagens que determina os processos de imaginação. Ou seja, não basta somar fragmentos do real percebido e do real vivido para atingirmos o domínio de uma imaginação fundamentalmente criadora. Para Bachelard (2008b) a imagem percebida e a imagem criada são duas instâncias psíquicas muito diferentes e seria preciso uma palavra especial para designar a imagem imaginada Bachelard (2008b, p. 3). Desse modo, a partir desta distinção, explica que tudo o que se tem referido sobre a imaginação reprodutora deve ser creditado à percepção e a memória. Cabendo a imaginação criadora a função do irreal que é psiquicamente tão útil quanto a função de real. Neste sentido o autor coloca a imagem da imaginação criadora antes mesmo da percepção, e tal imagem como uma aventura da percepção. Buscar o sentido e a origem das imagens novas que delineiam a sensibilidade contemporânea é perscrutar, ainda que modesto, um panorama! Pois seguindo a orientação bachelardiana, um fenomenólogo deve ser sistematicamente modesto. Assim, buscaremos nas obras aqui selecionadas a novidade das imagens, sua capacidade de surpreender e ao mesmo tempo conservar sabedorias míticas. 


\section{AS ARTES VISUAIS, AS IMAGENS E O IMAGINÁRIO: TRAÇOS DO CONTEMPORÂNEO}

Diversas imagens da atualidade corroboram com a filosofia de que estamos no tempo da fluidez. Como, por exemplo, a arquitetura flutuante de Frank Gehry que se multiplica pelo mundo e encontra sua expressão emblemática no Guggenheim Bilbao, na Espanha Arantes (2012). As formas de Frank Gehry flutuam e fluidificam como ondas, como corpos líquidos que se solidificaram em formato de edifício. Uma arquitetura aérea, fluida, reluzente, plena de dobras impressionantes e fantásticas que nos chegam como imagens fixadas no presente a aludir sobres as paisagens que teremos no futuro. E não para nas imagens visuais, essas formas tem incluído sons, sensações táteis, odoríferas.

Em 2016, visitando uma praça em Mônaco denominada La Roseraie da Princesse Grace, senti que os meus pés afundavam num trajeto para cooper. O caminho fora projetado para amortecer o impacto das corridas e caminhadas. Nessa experiência, uma sensação tátil inusitada e mesmo surpreendente que nos faz pensar sobre a construção dessas novas paisagens sensíveis e seus artifícios para intensificar o modo como sentimo-las. Quando olhamos para as artes, a cidade, a paisagem, contemporâneas, observamos essas características intrínsecas: uma valorização do grandioso, lúdico e impressionante no campo visual e uma preocupação com a sensação através de todos os sentidos. As novas paisagens parecem revelar uma atmosfera que se contrapõe aquela delineada ao longo da modernidade.

Criando paisagens já plenas de novas sensações, potencializando, artificializando os sentidos que as paisagens já perspectivam. De certo modo, a preocupação em forjar uma paisagem sensível acentua as perspectivas de percebê-la e vai ao encontro da própria evolução que o conceito de paisagem alcançou na abordagem geográfica. De certo modo, redescobrimos a paisagem quando ela deixa de ser somente campo visual e passa a ser compreendida através da articulação dos cinco sentidos nela presentes. Paul Claval (2012, p. 262-263) aborda sobre as mudanças ocorridas da década de 1970 para os dias atuais, o impacto e a influência significativa das filosofias fenomenológicas, pois o mundo percebido, o mundo das sensações é que permitem compreender as coisas como elas verdadeiramente são. Assim, podemos aferir que a verdade é, sobretudo, uma qualidade do ver com os múltiplos sentidos. A possibilidade de penetrar a dimensão subjetiva, o universo de signos que estão tanto na paisagem como no observador. Claval (2012) expõe sobre a percepção da paisagem que nasce do 
contato direto do viajante com as coisas e os seres. A visão, assim, interage com os outros sentidos para organizar uma compreensão maior do todo e para explorar as possibilidades e significados dessa interação retomo a famosa passagem de Marcel Proust para o qual "a verdadeira viagem de descobrimento não é encontrar novas terras, mas ter um olhar novo":

[...] fá-lo surgir para nós, exteriorizando nas cores do espectro a composição íntima desses mundos a que chamam indivíduos, e que sem a arte jamais conheceríamos? Asas, um outro aparelho preparatório, e que nos permitissem atravessar a imensidão, não nos serviriam de nada, pois, se fôssemos a Marte e a Vênus conservando os mesmos sentidos, eles reverteriam do mesmo aspecto que as coisas da Terra tudo aquilo que pudéssemos ver. A única viagem verdadeira, o único banho de Juvência, seria, não partir em busca de novas paragens, mas ter outros olhos, ver o universo com os olhos de outra pessoa, de cem outras, ver os cem universos que cada uma delas vê, e isso podemos consegui-lo com um Elstir, com um Vinteuil; com seus pares verdadeiramente voamos de estrela em estrela (PROUST, 2016, p. 202-203).

Essa mensagem nunca esteve tão atual, sobretudo, num momento em que o Google Earth põe lentes em todos os cantos do planeta a nossa tarefa de olhar o mundo torna-se mais sutil e complexa. As novas terras que a geografia encontra são, sobretudo, simbólicas e imaginárias. O olhar estrangeiro contém os componentes surpresa e encantamento que colaboram na transformação do olhar e do sentir. A partir do olhar estrangeiro renovamos o modo como vemos as nossas próprias paisagens, faz-nos redescobri-las. Na esteira de Proust, não teria a arte esse mesmo poder em seu território? O espaço e o tempo "amolecem" de diversas formas. Não é por acaso que um filósofo da envergadura de Bauman (2001) assegura sobre a necessidade de ser leve e líquido, para o autor estamos vivendo a era dos fluídos, cujas qualidades fundamentais estão em não se fixar no espaço e nem prender-se no tempo. Sobre a fluidez contemporânea, Bauman (2001) afirma utiliza-la como a principal metáfora para o estágio presente da era moderna. Para o autor a extraordinária mobilidade dos fluidos é o que os associa a ideia de leveza: “Os fluídos se movem facilmente. Eles 'fluem', 'escorrem', 'esvaem-se,' 'respingam, 'transbordam', 'vazam', 'inundam', 'borrifam', 'pingam'; são 'filtrados', 'destilados'” (BAUMAN, 2001, p. 8). Há uma profunda relação com o transitório, com a passagem, mas ao mesmo tempo, um forte detimento na significação, pois impressionam os nossos sentidos e os articulam. A arte contemporânea cria suas paisagens com essa mesma atmosfera. Vislumbremos a obra de Ernesto Neto no Museu Guggenheim Bilbao, nesta instalação intitulada “Um Corpo 
Que Cai" (ver figura 1) a obra dialoga com a própria forma arquitetônica do Museu Guggenheim a fluidez externa da sua arquitetura encontra a linguagem líquida da instalação de Ernesto Neto. De certo modo, seguindo a perspectiva de Bauman (2001, 2007), podemos dizer que a modernidade derrete por dentro e por fora no museu. Grandes e longas gotas brancas escorrem flutuando. Tornam a paisagem emocional, há paz, silêncio, sensualidade. Observando-a nós desfrutamos sua paisagem mole, compôla é "certamente" um deleite! Latex ou Leite, Narcisos brancos? É possível imaginar ao infinito.

\section{Figura 1 - O corpo que cai de Ernesto Neto. Exposição Museu Guggenheim Bilbao,} 2014

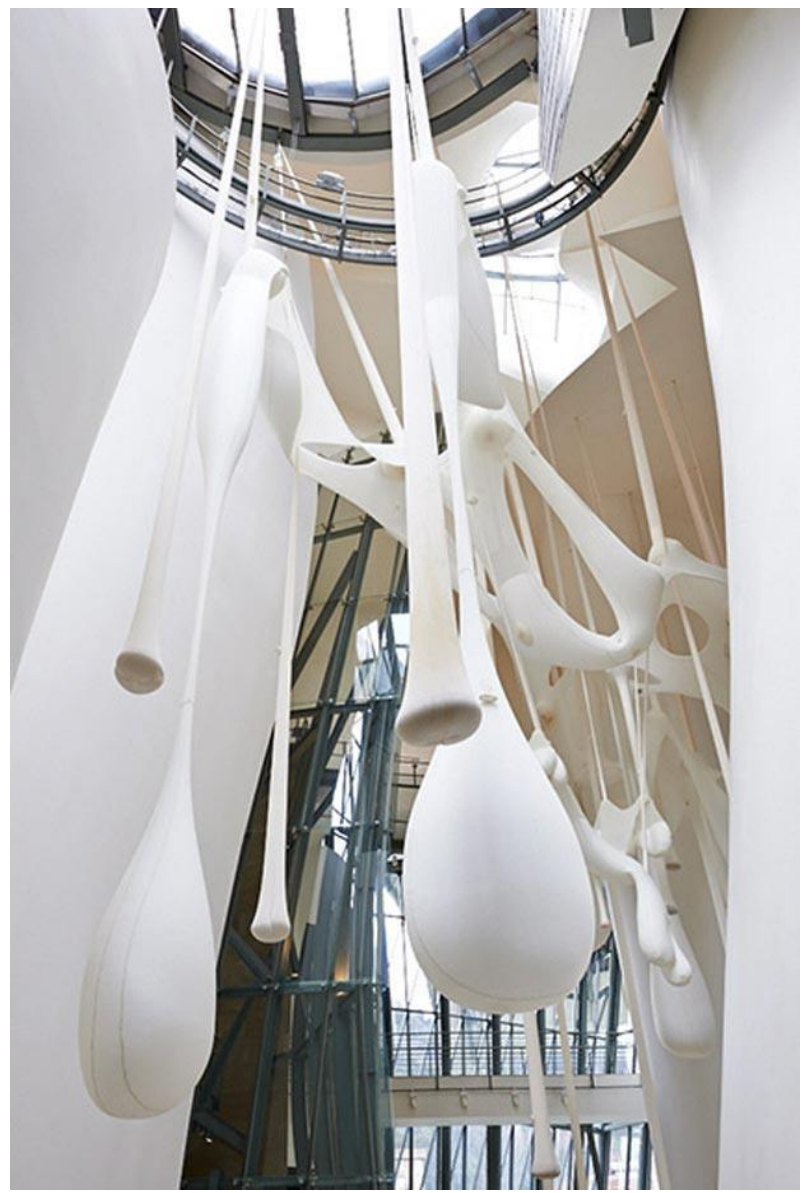

Disponível em: <https://veredes.es/blog/en/ernesto-neto-el-cuerpo-que-me-lleva/>. Acesso em: 11 nov. 2017.

Observaremos a fluidez não apenas como metáfora, mas como imagem no sentido da fenomenologia bachelardiana. A a liquidez parece fazer parte da emoção contemporânea e no imaginário das artes escorre de diversas formas. 


\section{IMAGENS IMAGINADAS: PAISAGENS LÍQUIDAS}

O imaginário transporta os jogos de signos do mudo, recolhe símbolos, cogita universos alternativos nas dobras dos tempos. Na obra de Vinícius Souza de Almeida, intitulada Lágrimas de São Pedro (ver figuras 2 e 3) a liquidez apresenta-se, e como a obra de Ernesto Neto, na Espanha, essas paisagens ganham o mundo, a exposição de Vinícius S. Almeida, depois de percorrer o Brasil, seguiu para Frankfurt na Alemanha ${ }^{4}$. O tempo e o espaço escorrem nessas obras, as paisagens líquidas agradam muito, admiramos o tema da água. A obra Lágrimas de São Pedro consiste em milhares de gotas num espaço que nos envolve, mas há amplidão. $\mathrm{O}$ espaço está cheio de água e também repleto de significados. Desde da evocação para a questão ambiental da água até uma poética líquida amorosa que nos faz ficar dentro da chuva, uma chuva imaginária plena de infinitas gotas de sonho a envolver-nos. A beleza das gotas que se fixam em plena "precipitação" e, de repente, estão suspensas, podemos contempla-las, adentrá-las, tocá-las, sentir a transparência. Imaginamos a enorme felicidade de quem atravessa essa obra, ela instaura um espaço lúdico. Sua amplidão faz uma paisagem líquida de um modo diferente: aos mesmo tempo que em escorre, estão congeladas.

\section{Figura 2 - Lágrimas de São Pedro - Exposição de Vinícius Souza de Almeida (Vinícius S.A.), 2014}

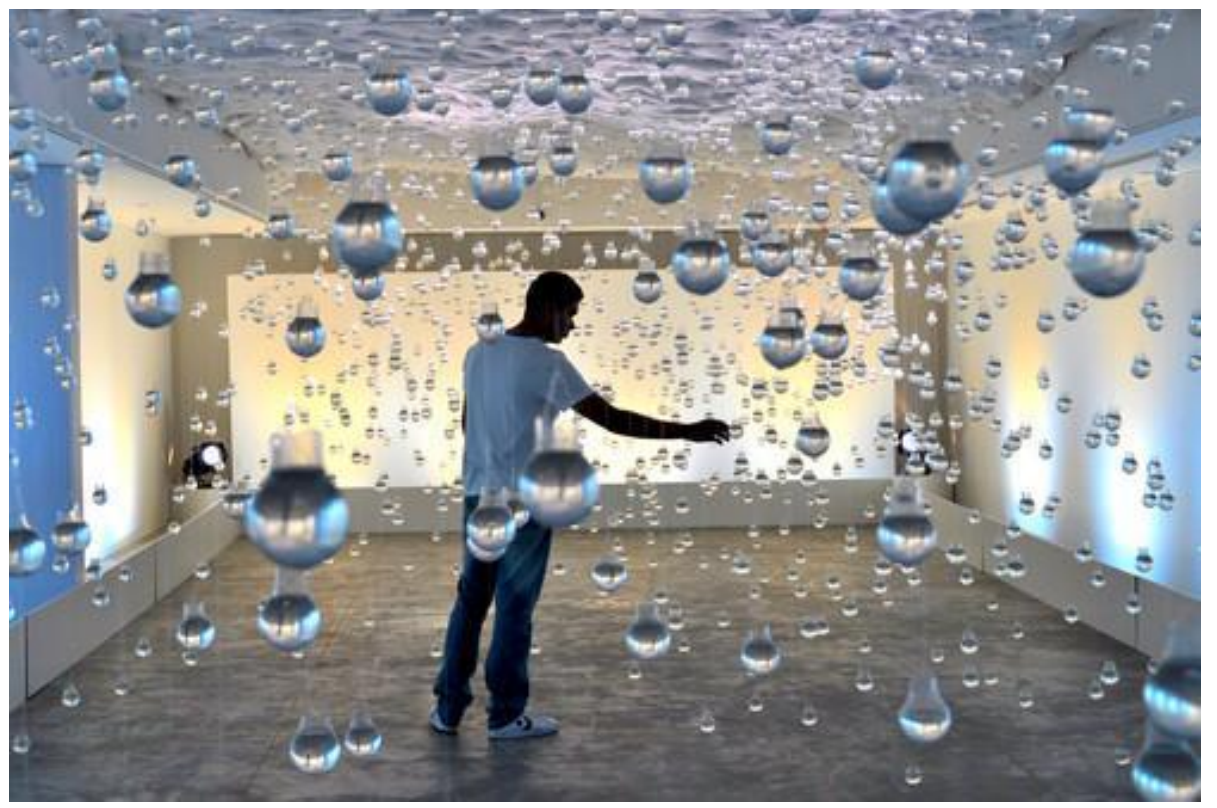

Foto: Erivan Morais Fonte: Disponível em: <https://www.facebook.com/Lágrimas-de-São-Pedro319452384833076/?fref=photo >. Acesso em: 21 nov. 2015.

\footnotetext{
${ }^{4}$ Informações obtidas no site https://www.facebook.com/Lágrimas-de-São-Pedro319452384833076/?fref=photo.
} 


\section{Figura 3 - Lágrimas de São Pedro - Exposição de Vinícius Souza de Almeida (Vinícius S.A.), 2014}

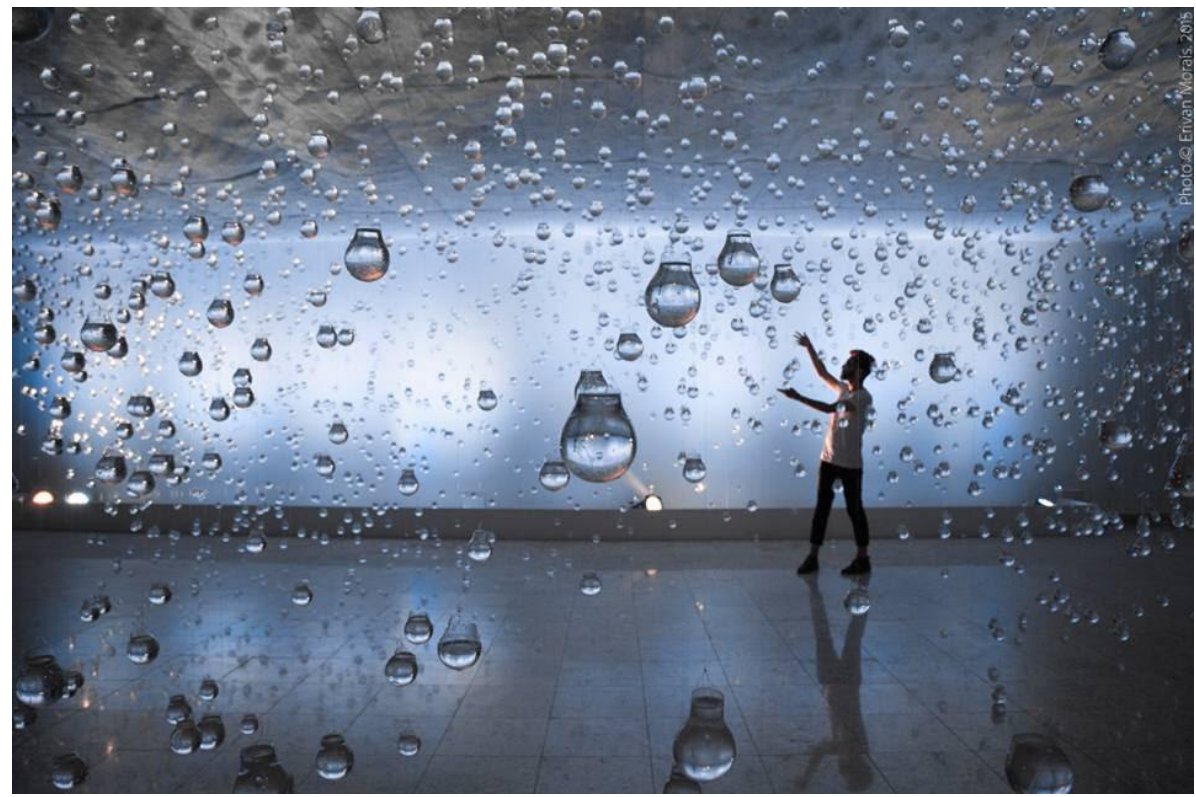

Foto: Erivan Morais Fonte: Disponível em: <https://www.facebook.com/Lágrimas-de-São-Pedro319452384833076/?fref=photo>. Acesso em: 21 nov. 2015.

Estar nesta chuva de grandes gotas é penetrar uma atmosfera de sonho! Duplamente fluída, une o aéreo e o líquido! Dialoga com os estados da matéria e é possível ser interpretada com os sentidos da imaginação material, Bachelard (1997, 2001) porque participam dos sonhos da água e do ar. Uma simbologia preciosa, quantas mitologias saem da água e voam com o vento! Essas matérias estão impregnadas de sentidos.

A obras de arte que tomam as formas líquidas e aéreas não se destinam apenas a nos encantar, mas parece conter um invólucro imaginário da transformação da "realidade" em ficção. O que descobrimos quando habitamos uma obra poética? Quando adentramos o novelo de mistérios no qual a realidade é apenas uma dimensão, uma perspectiva, um ponto de vista? Tal novelo tem um fio fino, dourado, responsável por tecer a existência cada vez mais enovelada. À medida em que o conhecimento avança, perde-se o sentido dualizar realidade e ficção, ou mesmo realidade e imaginação. Qualquer estudo mais profundo pode revelar a dobra de uma dimensão na outra, para o qual uma não existe sem a outra. Não podemos conceber a realidade sem imaginação e tampouco a imaginação desprovida da possiblidade de tornar-se real, de ser real. Imaginação é uma realidade em potencial no mundo pós-moderno, tecnologizado, virtual. Realidade e ficção são dimensões sobrepostas. Somos essencialmente seres imaginais e simbólicos inseridos em contextos ditos "reais". 
Quando descobrimos que o real é filtrado por representações e, ainda mais, pela capacidade que tempos de transformá-lo, o que chamamos de real é sempre um contexto efêmero, uma condição momentânea, mutável ao sabor do tempo e da imaginação. O Real é também um possível dentre tantos possíveis. Assim, podemos nos arriscar e dizer que o real só se efetiva na imaginação, nas dobras da representação cercada de tantas variáveis, de tantos lastros deslocados, de tantas presenças da ausência, de tantas ficções aderentes, de tantos intangíveis. A imaginação tem um poder imenso. E quando quer, abre suas enormes asas conforme Pensanha (1985). Num real gasto, monótono a imaginação tem o poder de dar continuidade a marcha do tempo. Nesta orientação, seguindo o percurso bachelardiano: a imaginação "dá a partida" da realidade, como dá a partida da imagem. O estudo da imaginação ocupa- se da imagem em nossa consciência, lapidando nela o mistério da matéria, suas tramas simbólicas, hermenêuticas, míticas. Bachelard (1994) elenca três pontos que constitui-se como uma noção importante para pensar a relação com a obra de arte. Pressupõe uma atitude contemplativa da própria obra, o aspecto local e temporal, o estado lírico e o trânsito: De Valéry, ele aprecia sobretudo a arte perturbar a calma e de acalmar a perturbação, de ir do coração ao espírito para retornar logo do espírito ao coração (Bahcelard, 1994, p. 133). Adentrar a obra de arte é imergir numa infância eterna do ponto de vista criativo, uma infância reencontrada, sempre possível, abrindo diante de nós um porvir indefinido. Desenha-se assim, um método de deslumbramento sistemático que reencontra olhos maravilhados para ver espetáculos familiares. O encantamento é lançar os sentidos com ímpeto sobre o maravilhoso e o mistério do desconhecido que há nele (Bachelard, 1994). O sonilóquio de um sonhador remete-nos ao contrassenso de pretender estudar sua obra objetivamente e só percebemos verdadeiramente a imagem quando a admiramos.

Uma imagem conecta-se a outra, ramifica-se, transmuta-se se em outra e engendra sentido, paradoxalmente, formando uma estranha unidade no inacabamento, na abertura. A liberdade da atividade imaginária em criar imagens mútuas e múltiplas, por vezes, complexas como a poética escultórica de Laura Vince, Warm White (ver figura 4) que concilia contrários e elabora uma trama ao reunir na obra os seguintes materiais: o mármore e o bronze, o vidro, a areia, a água no estado líquido e vaporoso, tubos de plástico, mangueiras. Palhares (2008) aborda sobre tal união de materiais nobres, tradicionais da arte escultórica, com os materiais simples do cotidiano e aborda sobre as transformações resultantes de tais relações, que propicia ao espectador a 
intensificação de uma experiência na qual "noções tão incomensuráveis como o tempo, o vazio, o silêncio evocado pelo branco das bacias de mármore tornam-se subitamente sensíveis" Palhares (2008), ao mesmo tempo em que também se percebe a ação do vapor por dentre as mangueiras, o aquecimento, o fluxo de água. A artista busca não eliminar a tensão entre opostos segundo Palhares (2008) e retira da presença simultânea do cheio e do vazio, da atividade e do repouso, do sólido e do líquido e, principalmente, de tudo aquilo que ocorre entre eles uma relação. Da dinâmica interativa, algo que pode ser percebido pelos nossos sentidos. O branco e frio do mármore em choque com o calor provocado pelas resistências que aquecem a água e a faz circular: uma poética do fluxo, da passagem, das relações. Naves (2011) interpreta a obra de Laura Vinci como "proliferação de vínculos entre regiões e lugares distintos, constituindo assim uma trama contínua e heterogênea que possibilita a todos nossos sentidos experimentarem uma potencialização de suas capacidades". Há uma interessante geografia nessa obra. A exposição que visitei em 2008 Warm White apresentava-se no enorme salão da Pinacoteca do Estado de São Paulo. A obra reunia dezenas de bacias interligadas por uma dinâmica de fluxo composta de cheios, e vazios. A fragmentação e a interligação interagia com a nossa capacidade de apreende-la, de percebe-la nos fluxos que constituem sua poética e se destacam as possiblidades de abertura, o espalhamento da obra, seus enigmas. Tal obra lembra ainda enclaves, nichos conectados por redes, por fluxos a qual se pode fazer uma alusão à dinâmica impressa também nas nossas cidades, repleta de fragmentos ligados por linhas, por fluxos e por diversas infraestruturas ou ausência delas em relações tensas. Por densidades distintas, bacias isoladas com amplo espaço, abertura e bacias amontoadas às quais podemos aludir as distintas e não equilibradas densidades da urbe. "A cidade converteu-se num arquipélago de enclaves modernizados-com suas torres corporativas, shopping centers e condomínios fechados cercados por várias áreas abandonadas, terrenos vagos..." (PEIXOTO, 2004, p. 393). De certo modo, pude associar essa obra, no amontoado e no vazio, nas conexões das mangueiras transparentes e em tudo mais com a descrição da cidade contemporânea, semelhante aquela que faz Peixoto (2003). Porém, tudo está em interdependência, tudo está em relação, está em conexão. 


\section{Figura 4 - Laura Vinci: Warm White (1980)}

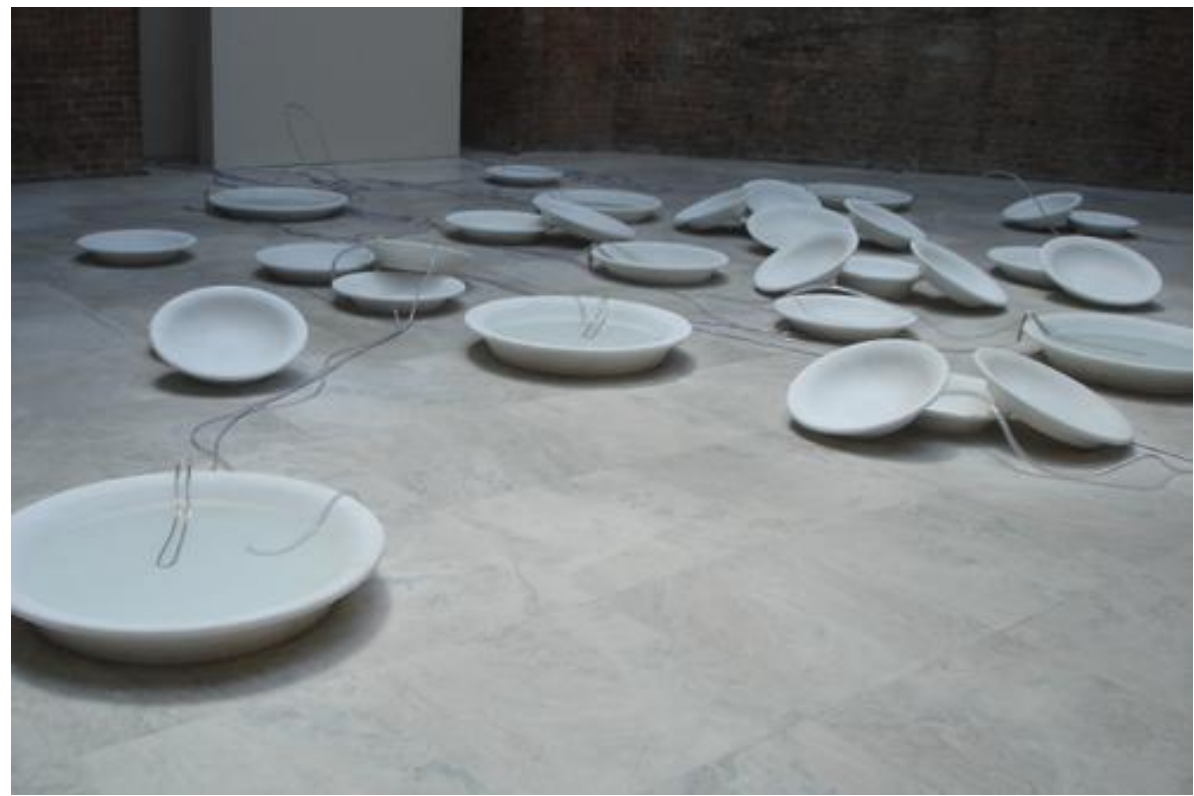

Exposição na Pinacoteca do estado de São Paulo, visita em 02 jan. 2008. Foto de Givaldo Corcinio.

Outros exemplos, onde conjugam-se trânsito, multiplicidade, complexidade, pluralidade, leveza, flutuação, fluidez e confluência dos sentidos, assim como, o impulso para a fábula que caracteriza a sensibilidade contemporânea são as obras escultóricas obras de Nele Azevedo, Li Hongbo e a instalação de Adriana Giora (ver figuras 5, 6 e 7), tratam-se obras fluidas, elaboradas com os mais inusitados materiais, papel de seda, mel, tecido e gelo entre outras. São poéticas que detém narrativas específicas $^{5}$ e desligam-se da ideia dos materiais tradicionais e, principalmente, desligam-se da ideia de permanência. São obras que escorrem e transcorrem, são as artes que parecem compreender muito bem o significado de tempo fluido, líquido, flutuante e esvoaçantes e ocupam as galerias dos museus e espaços culturais. São também obras que segundo Archer (2001) são feitas para observar e não consumir, pois, observar a arte não significa consumi-la, mas sim tornar-se parte do mundo ao qual pertencem essa arte e esse espectador. Buscar na sua fluidez coisas que permanecem imutáveis. Contemplação, reflexão e experiência é o que contam.

Desse modo, o corpo fluido da escultura de Li Hongbo é o homem a paisagem que escorre.

\footnotetext{
5 Obra de Nele Azevedo - artista brasileira que expôs as esculturas de gelo na Alemanha em 2009. Esta exposição deteve uma narrativa ambiental, a mudança climática e o aquecimento global, pois as centenas de frágeis esculturas feitas à mão pela artista foram expostas ao sol e derreteram em minutos como um símbolo das mudanças climáticas globais, BBC (2009). Ver <http://www.bbc.com/portuguese/multimedia/2009/09/090902_esculturagelo_video.shtml>.
} 


\section{Figura 5 - Escultura de Li Hongbo}

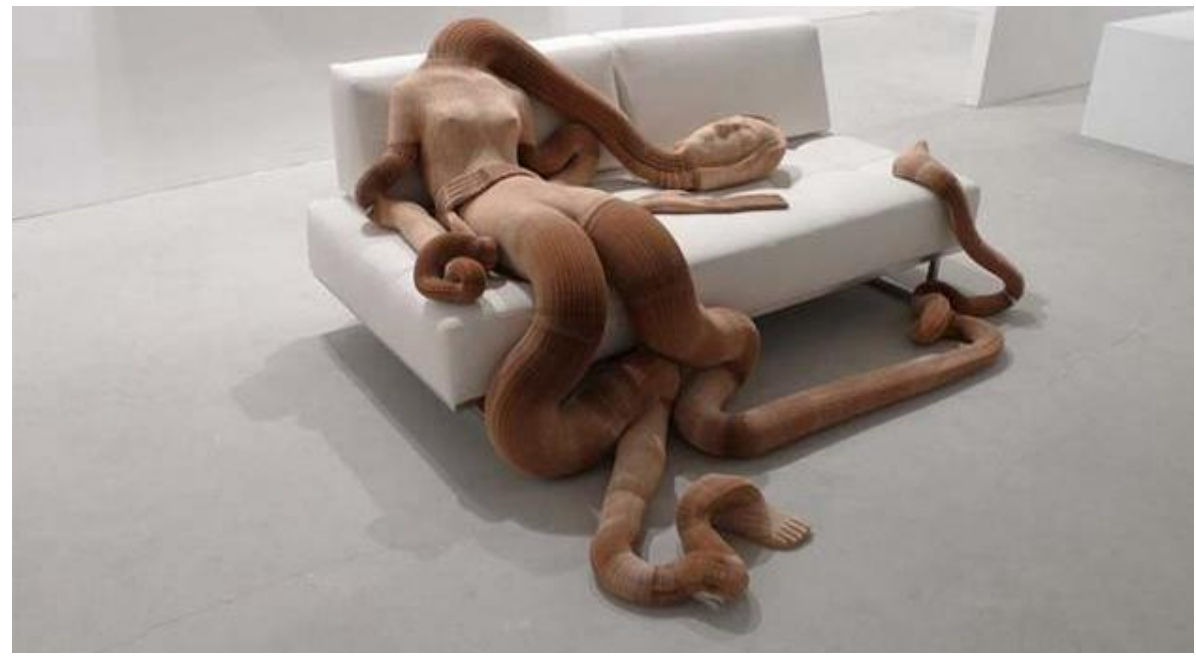

CARVALHO, Vicente. Complexas e inovadoras esculturas de papel coladas com mel. Disponível em: <http://www.hypeness.com.br/2013/02/complexas-e-inovadoras-esculturas-de-papel-coladas-com-favosde-mel/>. Acesso em: 08 jun. 2013.

São paisagens líquidas, o corpo que escorre numa poltrona, as medusas flutuantes ou as figuras que degelam. De maneira alusiva ou com a presença material da água essas imagens dialogam entre si. O corpo de Li Hongbo e os pequenos corpos de Nele Azevedo, colocam em perspectiva que também nos liquifazemos, também escorremos nesse tempo veloz. Somos essa paisagem líquida e não estamos fora dela.

\section{Figura 6 - Mistérios de Adriana Giora}

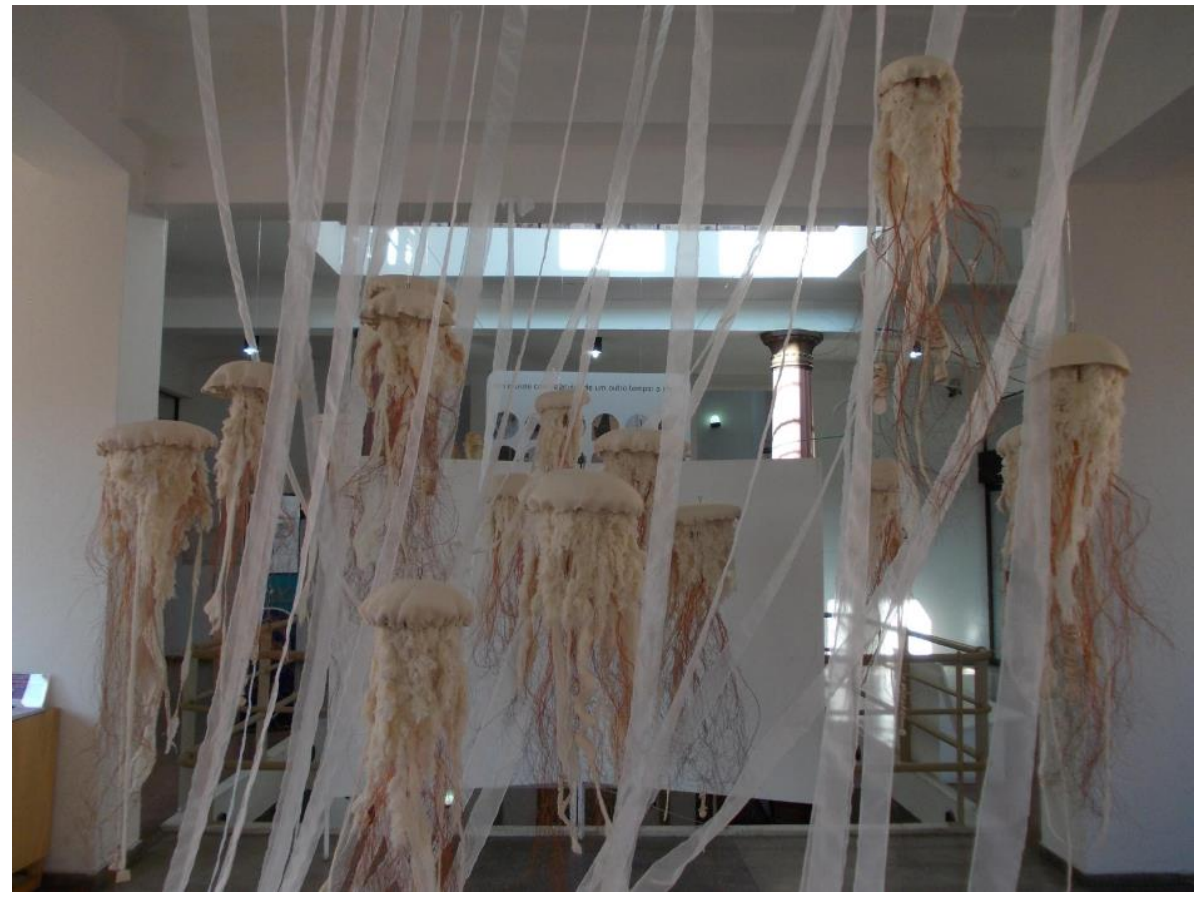

Instalação na I Bienal Chico Lisboa. Espaço Cultural Casa de Mário Quintana, Porto Alegre - RS, 2015. Foto de Valéria Cristina Pereira da Silva. 
As medusas de Adriana Giora em Mistérios, por sua vez, flutuam numa paisagem aérea cheia de fitas em alusão aos mares. A medusa é um ser que se confunde, em sua transparência, com a própria água - as águas-vivas - a medusoza é como se fosse uma chuva viva dentro dos oceanos. São seres sensíveis, cheios luminosidade formados quase totalmente de água. Não é a medusa um corpo líquido?

Já as delicadas figuras de gelo nos degraus de uma escada qualquer, de uma cidade global, uma paisagem-tempo constituída de efemeridade e rapidez. Do gelo ao líquido sem continente, obras vinculadas à multiplicidade simbólica da água como vida e morte, como tempo no sentido heraclitiano. Uma mise en scéne existencial que adquire um valor de fábula em sua conotação moral, aquilo que a obra busca despertar.

\section{Figura 7: Obra "Homens de Gelo" de Néle Azevedo}

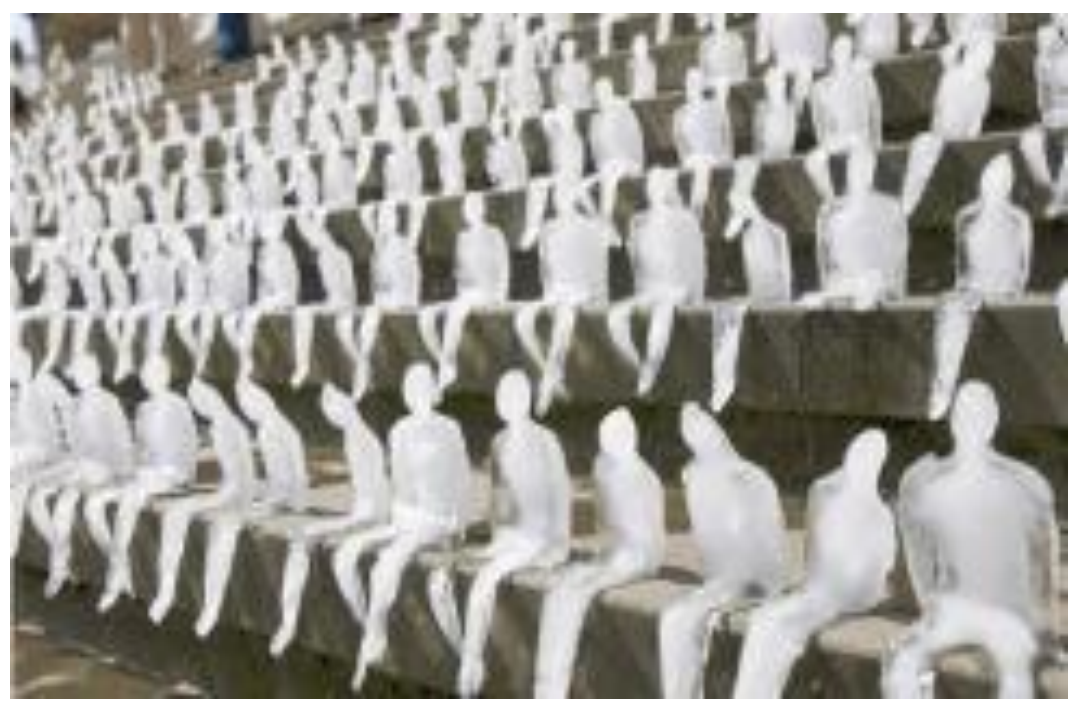

Disponível em:

<http://www.bbc.co.uk/portuguese/multimedia/2009/09/090902_esculturagelo_video.shtml>. Acesso em: 15 ago. 2013.

Essa obras remetem-nos ao ser destinado a água, um ser em vertigem, de acordo com Bachelard (1997) pois, a cada minuto, alguma coisa de sua substância desmorona constantemente. Porém, o poeta mais profundo encontra a água viva, a água detentora dos segredos. A mesma lembrança sai de todas as fontes. Na mitologia, de acordo com Nardine (1982), trata-se da fonte de Mnemosine, deusa da memória e mãe das nove musas inspiradoras da poesia e das outras artes. A fonte da memória jorra, assim como escoa o Lete, o rio do esquecimento. Lembrança, recordação e esquecimento também estão atrelados a imagem da água. "Sonha-se antes de contemplar. Antes de ser um espetáculo consciente, toda paisagem é uma experiência onírica. Só olhamos com 
paixão estética as paisagens que vimos antes em sonho" (BACHELARD, 1997 p. 5). As paisagens mais oníricas são aquelas vinculadas a fluidez.

\section{O LUGAR EM ESTADO FLUÍDO: O FLUTUAR DAS BOLHAS NA ARTE}

Vamos reunir e observar as imagens da fluidez, o sentido da leveza e o simbolismo de algumas paisagens poéticas contidas nas obras do artista plástico e cineasta Cao Guimarães (2010) e do fotógrafo americano Tom Storm (2006, 2011). O recorte feito a partir desses dois artistas consiste nas imagens de fluidez das bolhas de sabão. Tom Storm $(2006,2010,2011)$ registra paisagens monumentais do mundo todo refletida em bolhas e as obras de Cao Guimarães os curtas-metragens $O$ Inquilino (2010) e Sopro (2000). Nas duas obras lugar e paisagem, respectivamente, adquirem um novo revestimento de significados. Parece ser possível, a partir de tais poéticas, identificar uma metafísica da bolha de sabão que caracteriza-se como uma imagem reveladora do contemporâneo. Nas palavras de Cao Guimarães (2017) Sopro evidencia este sentido: "Sopro" expressa a relação entre o que está dentro e o que está fora. O translúcido multiforme de uma bolha exibe o mundo que a contém e que é contido por ela. A bolha, que nunca explode, é uma metáfora para a continuidade das coisas (GUIMARAES, 2017). Grandes bolhas voejam pelo campo numa paisagem com palmeiras. Há muito vento, as bolhas transparentes envolvem as árvores como camadas visuais da atmosfera. Imagens em preto e branco que fazem dialogar o céu e a terra, as nuvens, o vento e as bolhas numa plástica "meteorologia poética" Bachelard (1993) em que se conjugam eternidade e instante. Ou como definiu Lygia Fagundes Telles no magnifico conto A estrutura da bolha de sabão: "A bolha de sabão é mesmo imprecisa, nem sólida nem líquida, nem realidade nem sonho. Película e oco" (TELLES, 1999, p. 157).

A bolha de sabão é feita de tempo e não tempo, é fugidia, é instante. O que lhe dá existência é o sopro, o mesmo sopro de vida que nos faz respirar põe em movimento a flutuação da bolha. Como um pulmão, a película de espuma enche-se de ar. Entre o sopro e o vento há na bolha um líquido, um cristal gelatinoso. Além de conter o ar e a água, agrega também os valores do cristal no sentido bachelardiano, reunindo os devaneios de pureza, de limpidez, neste aspecto semelhante aos devaneios da água com poder de purificação. Numa interessante associações de imagens "o cristal de rocha é uma água congelada [...] Victor Hugo escreve: o cristal é gelo sublimado" (BACHELARD, 2008b, p. 233). O que ocorre ainda quando essa fusão material encontra o gelatinoso? O labirinto simbólico do espelho é outro elemento que reveste a 
bolha de significados, já que esta tem a capacidade de refletir imagens. A bolha detém um arco-íris no seu globo. Uma irisação espelhada e ampla que alude à imagem e ao simbolismo da aurora boreal ${ }^{6}$ em seus halos de encanto e mistério. A forma arredondada da bolha contém sua natureza e revela um pequeno mundo, isso faz da simples bolha uma imagem poética sensível essencial. É uma imagem imaginária por excelência, profundamente complexa em sua singeleza, em sua beleza lúdica e encantadora. A bolha é um sinônimo da leveza, da flutuância, do ar e do voo. Lúdica e líquida, cristal espelhado, película de vento furtiva de cores boreais. Quem podem compreender essa multiplicidade? As bolhas de sabão multiplicam-se na arte contemporânea, em diversas expressões.

Nestes exemplos, selecionados conjugam-se fluidez e permanência, leveza e densidade numa multiplicidade de meios e significantes. A obra do fotógrafo americano Tom Storm que a partir de 2006, conforme com a matéria divulgada na BBC (2011), fotografa os monumentos de suas viagem em bolhas de sabão unindo o lúdico de sopralas com a complexa tarefa de fixar a imagem nela refletida numa interessante poética a ligar o que há de mais denso e permanente, que é o monumento urbano, às imagens arquitetônicas, ao leve, transitório, da bolha de sabão. Trata-se de um reflexo dentro do outro multiplicado as representações ao infinito: a eternidade dos monumentos, nos reflexos curvos, distorcidos, colorizados, efêmeros das bolhas. No primeiro momento, o efêmero, para em seguida, atar novamente a imagem à dialética da eternidade e do instante, já tão trabalhada na semiótica fotográfica. Quantas metáforas do próprio conceito de representação podem ser trabalhadas a partir dessa obra? Reflexo de reflexo? Fixar a partir do efêmero numa matéria plena de simbolismo, a bolha - cristal gelatinoso, repleto de ar, de sopro! Caberia uma intensa hermenêutica simbólica dessa poética, que evidentemente não poderemos empreender aqui, para sublinhar todos os significados dessas imagens em bolhas de sabão e englobar tudo aquilo que a envolve e tudo que é envolvido por ela. De acordo com Chevalier \& Gheerbrant (2001, p. 138139) a bolha plena de ar, por um lado, simboliza a criação leve, por outro, guarda um altíssimo sentido metafísico, espiritual e secreto, assim como, ar que ela contém. A obra de Tom Storm (ver figura 8 e 9) retém todas as possiblidades simbólicas, como imagem de um tempo sensível que reflete a si mesmo, um espectro irisado que guarda o visível e

\footnotetext{
${ }^{6}$ Ligada ao mito e ao simbolismo da cavalgada das Valquírias pelos campos a reluzir suas armaduras, emitindo um brilho radiante que iluminavam os céus, criando a claridade fulgurante e colorida do fenômeno que conhecemos como Aurora Boreal. Ver As Valquírias, Site: <http://3fasesdalua.blogspot.com.br/2011/10/as-valquirias.html>. Acesso em: 06 fev. 2016.
} 
o invisível. Do reflexo para a impressão: fotografia, escultura, arte urbana, poesia ou arquitetura? O mais provável é que essa poética reúna todos essas artes, construindo na imagem fotográfica a narrativa aberta de trânsitos entre o fluído, o flutuante e o permanente numa instigante presentificação que envolve um sublime sentido do tempo. Essa obra contém, retém o espaço. É espaço e paisagem e si mesma! Fragmentos de mundos vividos e sonhados. Paisagens postais que flutuam e se fixam reduplicando o seu sentido, ou seja, passam de fixas as flutuantes, das paisagens urbanas na cidade para paisagens urbanas nas bolhas, de flutuantes à fixas, da bolha para a imagem fotográfica e posteriormente para difusão nos meios digitais.

Fragmentos de Nova York, Chicago, Berlim, Compenhage, entre tantos outros flutuam agora nessas imagens que surgiram de uma intenção artística, mas também da leveza do acaso, Lemes (2017) explica que o projeto The World in a Bubble, teria surgido num festival de verão irlandês no qual Storm fotografava. Ele então teria visto as bolhas de sabão de um vendedor que estava por ali e as fotografou. Porém, ao examiná-las no regresso de sua viagem, surpreendeu-se com as imagens. Percebeu a perfeição da paisagem nelas refletidas. A partir de então $O$ mundo em bolha "guarda", recolhe paisagens multiplicado as formas de olhá-las, de acaricia-las, de lê-las. Na bolha agora a poética da paisagem adquire novas figurações da linguagem, ainda que a essência da identificação da paisagem se conserve. Collot (2013) afirma que toda paisagem envolve pelo menos três componentes numa relação complexa: um local, um olhar e uma imagem. Sendo que o olhar é que transforma o local em paisagem no pensamento de Collot (2013) e a partir daí sua artialização. Aqui a câmera-olho executa arte da paisagem revestindo-lhe de novas significações e a duplicação da paisagem no seu sentido próprio sentido visual como simbolismo da visão inerente à bolha. 


\section{Figura 8 - Foto de Tom Storm (2012)}

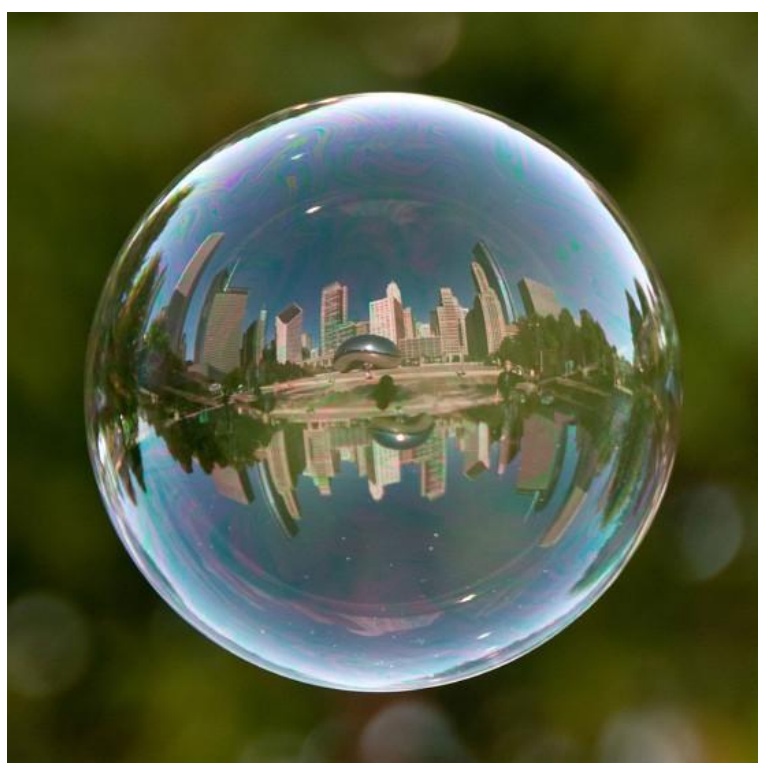

Fotografias de monumentos refletidos em bolhas de sabão. Arte de Tom Storm. Claud Gate, Chicago, EUA. Fonte:

<http://www.bbc.co.uk/portuguese/noticias/2011/09/110908_galeria_bolhas_rw.shtml>.

A obra está sujeita a movimentos contínuos. Os espaços porém, estão dentro da bolha na sua ilusão transparente de cristal, sujeitos aos mais variados processos de virtualização, a obra inaugura uma nova forma de ver essas paisagens cartões-postais. Por vezes, a olhamos como numa bola de cristal, sujeita a sua curvatura. A obra parece então dar nos poderes mágicos, poderes de visão. Identificamos nesta perspectiva a dimensão do devaneio, o imaginário, como possibilidade de habitar imagens novas que dão acesso a mundos não apenas recontados, mas mundos possíveis como afirma (Bahcelard, 2008b). Na imagem da bolha de Tom Storm a fluidez entre realidade e ficção também está colocada. A função do irreal apresenta a fluidez no modo como se fundem a realidade e a ficção. Esta é também uma questão-chave naquilo que denominamos sensibilidade contemporânea. O irreal figura como uma dimensão profunda da realidade. A imagem diz o que foi imaginado ao mesmo tempo em que joga com a identificação dos lugares. $\mathrm{O}$ autor trabalha a imagem no mistério da matéria da bolha, traça contornos do espaço afetivo no interior mesma. Põe a ver o invisível na sua transparência e através da imagem dos monumentos/lugres/paisagens o grão das substâncias. Valoriza extratos, tinturas, vai ao fundo das coisas, em busca de uma imagem final, como na filosofia da imaginação em Bachelard (2003, 2008b) "tateia" o mundo através dos modos de se relacionar com a imaginação, fenomenologicamente diluída no processo de apreensão e na não separação entre sujeito e objeto. 


\section{Figura 9 - Foto de Tom Storm (2012)}

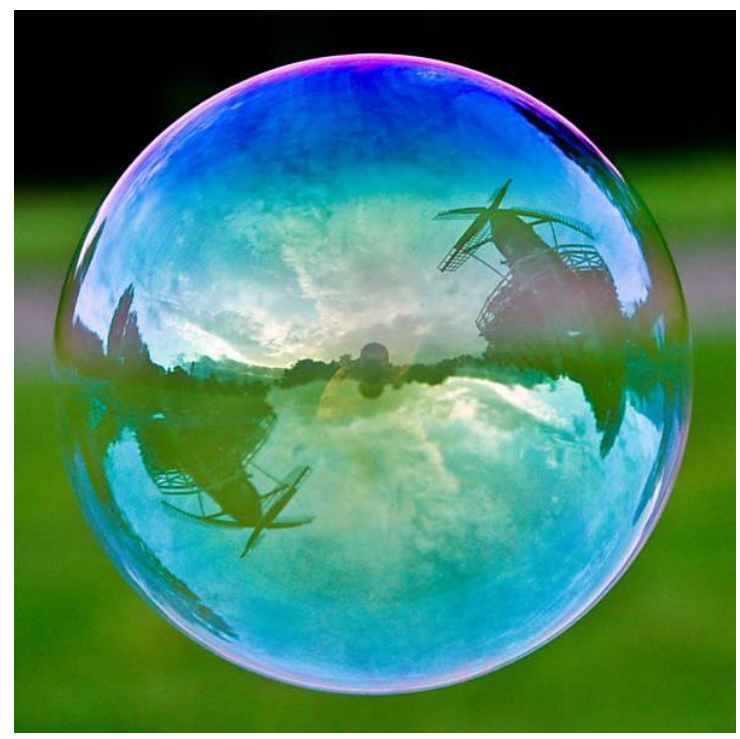

Copenhague, Dinamarca. Fotografias de monumentos refletidos em bolhas de sabão. Arte de Tom Storm. Fonte: <http://www.bbc.co.uk/portuguese/noticias/2011/09/110908_galeria_bolhas_rw.shtml>.

A bolha ${ }^{7}$ em $O$ Inquilino de Cao Guimarães, é um ser eterno no tempo que dura o filme. Sempre em movimento, em constante flutuância - a virtualização, a transparência, o reflexo, o irizado - valores da bolha - viajam por uma casa em reforma e vazia. A bolha em seu percurso entifica-se, torna-se uma presença, instaura a alusão de um olho vê, observa, examina, inspeciona, ilumina! No espaço vazio a poética da fluidez representa uma narrativa quase silenciosa, os sons que perpassam o filme são sons de passos, toques, talvez uma porta batendo, sons esparsados que acentuam o silêncio! Contudo, o espaço vazio está cheio de signos. A bolha transita no vazio por umbrais de tempo. Cada cômodo detém um piso diferente, pisos de diversas épocas como uma marchetaria do tempo. A reforma não está completa e a bolha transita por esses cômodos-tempo. Em uma passagem umbral, o corredor forrado de jornais, a bolha vai para o futuro, diante das paredes recém pintadas, a cerâmica branca do banheiro, lugar clean, que a bolha toca como se acariciasse. Uma parede cor rosa-choque, o tom quente em harmonia com o branco frio sugere a presença do feminino e instaura uma nova leveza. A escada parece ser outro umbral do tempo, dessa vez para o passado pois as marcas do envelhecimento estão nas paredes descascadas, nas cores escuras, o limo das cerâmicas. A bolha, porém, também toca essas superfícies como se pudesse sentilas. Será a reforma um apagamento? Mas o tempo ainda permanecerá no lugar. A casa guarda várias memórias que são reveladas nos armários, nos pisos, nas diversas formas

\footnotetext{
7 Ver site: Cao Guimaraes - <http://www.caoguimaraes.com/obra/o-inquilino/>.
} 
de janelas, nos azulejos com estampas de flores verdes na cozinha, imagens de antigamente em sua singeleza, em sua beleza e permanência. Isso significa que muito do passado permanecerá no futuro. A fluidez do espaço e do tempo parece rimar com a fluidez do inquilino. Num dado momento, a bolha parece atravessar uma lâmpada acesa, dupla imaginação do ser em sua luminescência, em sua possibilidade de transcendência. Ao descer as escadas a bolha encontra espaços opacos e mais escuros, mas ainda assim, não perde sua luminosidade. Há uma verdadeira casa-tempo na diversidade de cores e materiais que se apresentam e dialogam com o fluxo, com os reflexos e com percurso. Numa passagem ela aproxima-se e toca a janela, momento em que o reflexo das janelas na bolha formam dois olhos (ver figuras 10 e 11 ), as próprias janelas convertem-se em olhos no interior da bolha! (ver figura 11). Que fantástica alegoria de uma dupla janela da alma! Ou também ver nos olhos da bolha a figuração da chama de uma vela, de uma lamparina íntima! Bachelard (1989) afirma que a chama é, dentre os objetos do mundo, aquele que mais nos faz sonhar é um dos maiores operadores de imagens. Ela nos força a imaginar, diante dela o que se percebe não é nada diante do que se imagina. As mais frias metáforas transformam-se em imagens. O ser da bolha de Cao Guimarães tem dois grandes olhos que brilham como chamas, sua presença vai pouco a pouco tornando-se uma magia, condensando muitos valores da visão, os olhos, o reflexo, a bola de cristal, o espelho, a duplicação da própria janela (ver figura 10). A janela da alma é ao mesmo tempo presença da magia e divinal aparição:

[...] o budismo faz da bolha a imagem da anitya, a impermanência do mundo manifestado: Aquele que olha o mundo como se olha uma bolha de ar, lê-se no Dhammapada, esse é capaz de não mais ver o reino da morte. Um outro sutra assegura que os fenômenos da vida podem ser comparados a um sonho, um fantasma, uma bolha de ar, uma sombra, o orvalho brilhante como um espelho, o clarão do relâmpago...Texto que indubitavelmente tem em vista o tratado taoísta T'ai-yi kin-hua tsong tche quando ensina que, no concernente ao Tao, o Céu e a Terra são uma bolha de ar e uma sombra. Joubert, mais próximo de nós, não escreve também que o mundo é uma gota de ar? (CHEVALIER \& GHEERBRANT, 2001, p. 138, grifos dos autores).

A bolha detém significados múltiplos, a fragilidade, a leveza, a poética, a metafísica, o mistério. Converte-se em numa imagem da sensibilidade, na obra de Cao Guimarães, uma sensibilidade da nossa época: poética encantadora e enigmática, trânsito pelo espaço vazio, mas impregnado de tempo, memórias da forma. Vi a obra $O$ Inquilino de Cao Guimaraes pela primeira vez na abordagem de Vidica (2017) sobre o tempo morto uma duração intelectiva presente nas imagens, bem como, os trânsitos 
entre a fortografia e o cinema, o borramento das fronteiras entre uma arte e outra e suas trocas de linguagens. Assistimos $O$ inquilino atentos as suas temporalidades, expressões e representações. Reconheci na casa um labirinto de épocas, pisos e janelas fragmentos de tempos, retalhos entre o passado e o devir. A bolha-olho também sugere que há lentes em todos os cantos, sua presença faz do espaço vazio um lugar. O mundo lá fora quase inexiste, não há referências de onde se localiza a casa. O externo é visto através do vidro de uma janela fechada, há plantas no exterior sugerindo que existe um jardim a ser contemplado, mas sua paisagem é um fragmento na transparência do vidro, no recorte da janela. A casa, assim, participa do mesmo tipo de visualidade da bolha, a própria casa é uma bolha, um ser-lugar. Armando Silva (1996) afirma que o lugar no contemporâneo é uma criação imaginária e não um constrangimento material, pois, o que se passa em nossa mente depende do lugar. As novas geometrias incluem a projeção curva no interior de uma esfera abstrata que, na visão do autor, traz a imaterialidade do lugar e faz com que este seja uma bolha de sabão que se desfaz no ar. O lugar como uma bolha torna-se um fenômeno da realidade expressa na pós-vanguarda, nas palavras do autor. O lugar tal qual a bolha adquire a mesma fluidez.

\section{Figura 10 - Cena do Filme "O Inquilino", de Cao Guimarães (2010)}

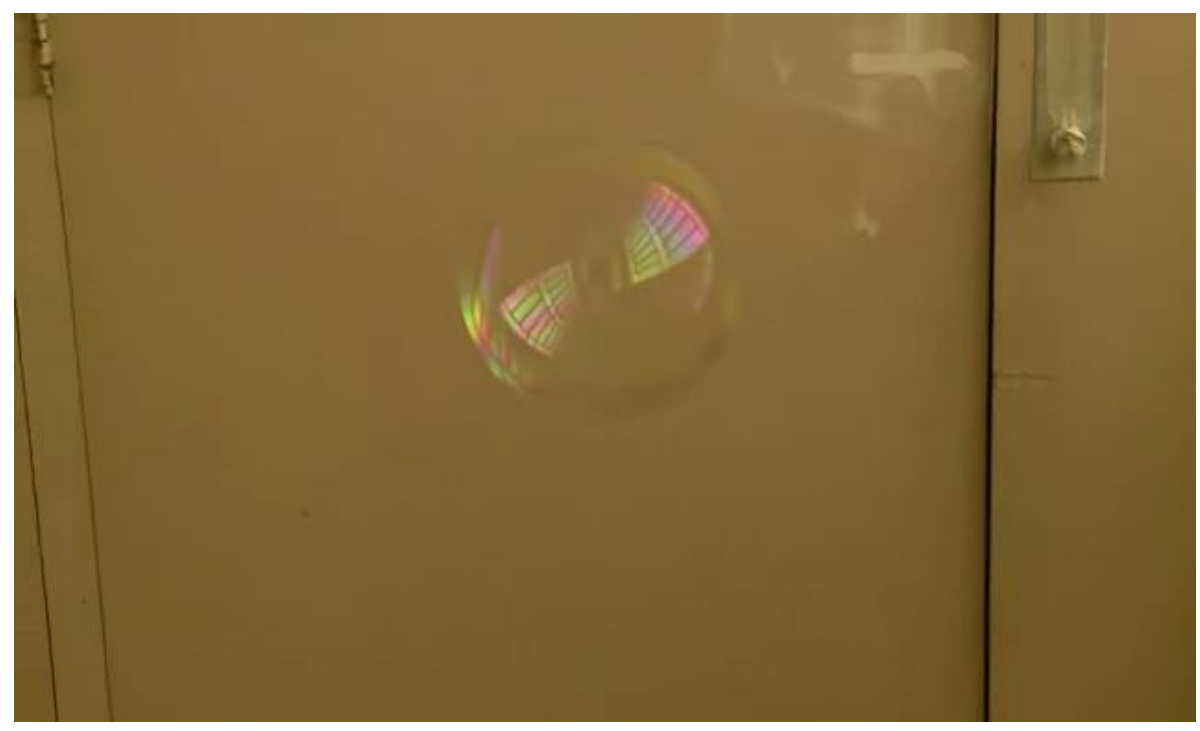

Disponível em: <http://www.caoguimaraes.com/obra/o-inquilino/>. Acesso em: 11 nov. 2017. 


\section{Figura 11 - Cena do Filme "O Inquilino", de Cao Guimarães (2010)}

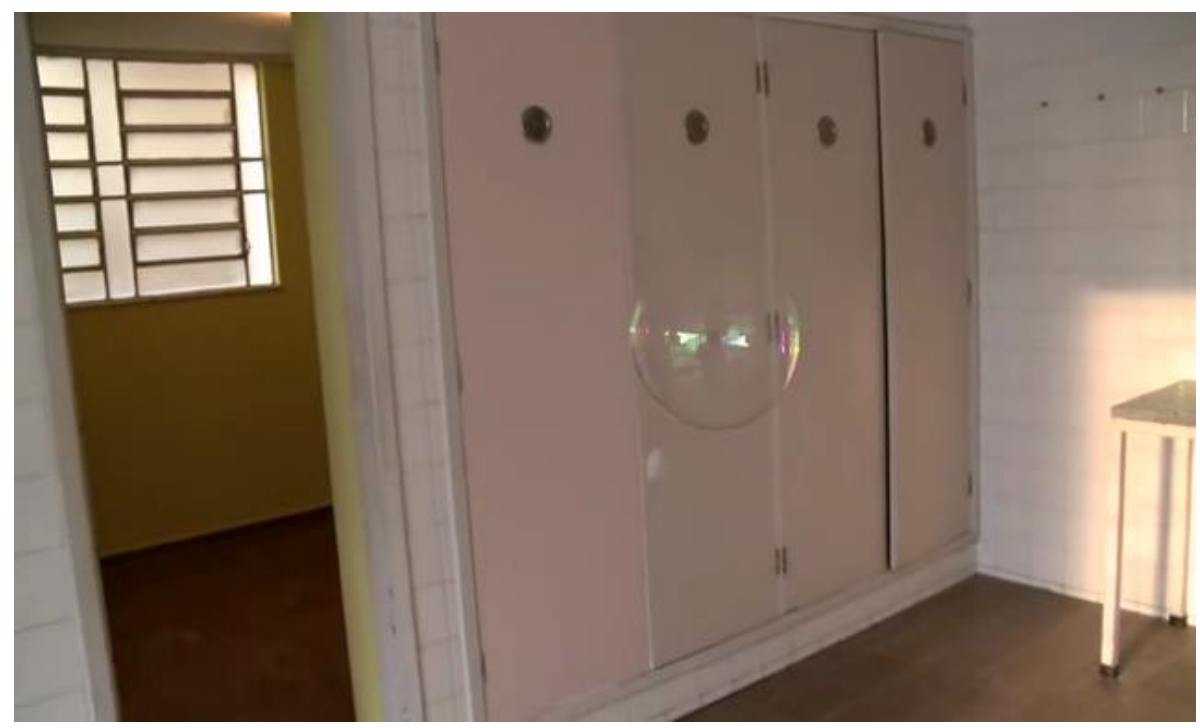

Disponível em: <http://www.caoguimaraes.com/obra/o-inquilino/>. Acesso em: 11 nov. 2017.

A poética do espaço une-se a da bolha, amplia a topofilia do espectador, cogita sonhos, justapõe tempos, aglutina-se as nossas lembranças. Evoca sentidos oníricos que vislumbram o futuro.

\section{A EMERGÊNCIA DO SENSÍVEL: A ATMOSFERA DO TEMPO}

A emergência do sensível consiste nas manifestações artísticas que trazem a experiência dos sentidos e compõe o variado leque da arte contemporânea. Trago aqui a experiência de ter visitado na X Bienal do Mercosul, em 2015, em Porto Alegre, dentre várias exposições, aquela que, particularmente, chamou-me mais a atenção, intitulada: Olfatória: $O$ Cheiro na Arte. A exposição criava várias atmosferas a partir do odor e instalava uma paisagem de sentido. A primeira obra a receber-me foi Gira de Alexandre Vogler - um peça formada de arruda e motor (ver figura 12) a peça remeteu-me uma espécie de lustre que girava em profusão, porém, o inusitado lustre herbal exalava um forte odor o qual me fez perceber que o cheiro é capaz, por si só, de criar uma paisagem. 


\section{Figura 12 - Gira, de Alexandre Vogler (2014), Arruda e Motor}

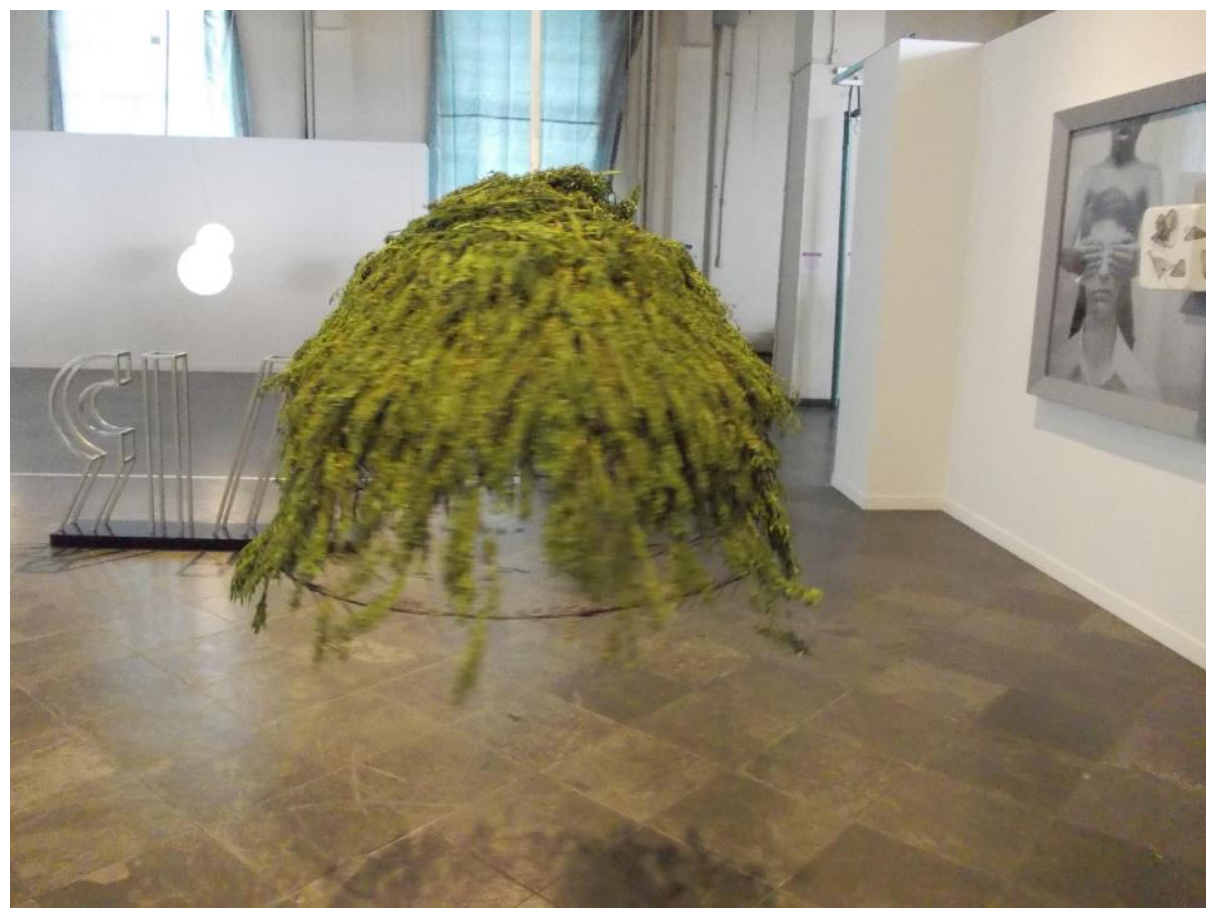

Exposição X Bienal do Mercosul, Espaço Usina do Gasômetro. Porto Alegre - RS, 2015. Foto de Valéria Cristina P. da Silva.

$\mathrm{O}$ arruda e seu particular odor, dentre tantos sentidos que evoca, associa-se a benzimentos, rezas, erva da mandinga que nos lança a uma atmosfera mágica. Desse modo, os demais sentidos já começaram temperados, benzidos pelas impressões do arruda, indução perceptiva ao estado de contemplação. O seu cheiro é verde, a paisagem que evoca é verde. As obras olfativas conduzia a diversas surpresas que possibilitam novas reflexões, por exemplo, a peça de Oswaldo Maciá - Quien limpia a quien tratava-se de um sabonete, semelhante aos sabonetes de ervas medicinais que conhecemos, acomodado em uma saboneteira de porcelana vitoriana e fechado num recipiente de acrílico com furos para que pudéssemos cheirá-lo. Porém, a surpresa era o cheiro do sabonete feito de alho. A visão induz a um conceito, mas o odor desconstrói essa expectativa. Muitas obras dessa mostra podem ser citadas como exemplo da pluralidade, da multiplicidade de materiais, por vezes, inusitados que caracterizam a arte contemporânea em sua novidade. Archer (2001) aborda sobre a profusão de estilos, formas, práticas e programas correspondente ao que se denomina arte contemporânea, sendo que esta pode utilizar além dos materiais tradicionais também o ar, a luz, o som, as palavras, as pessoas, comida entre outros, assim como o cheiro. Cada peça da 
exposição de Arte Olfativa mereceria uma análise cuidadosa, com seus vários artistas e propostas.

Figura 13 - Antes Que Eu Te Engula Carrocell Flower (2007), de Ernesto Neto

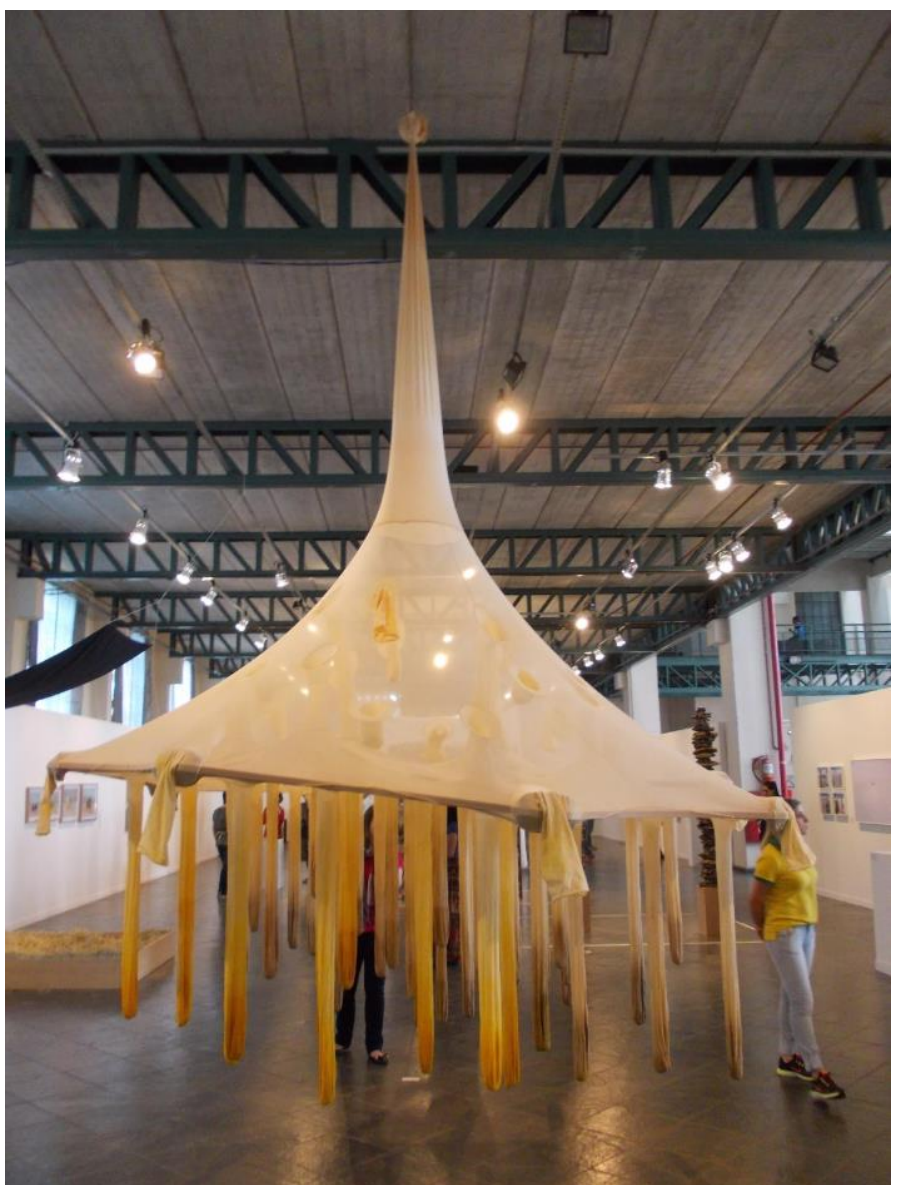

Exposição X Bienal do Mercosul, Espaço Usina do Gasômetro. Porto Alegre-RS 2015. Foto de Valéria Cristina P. da Silva.

Porém, deterei-me em três obras: Antes Que Eu Te Engula Carrocell Flower de Ernesto Neto, O Círculo dos Prazeres de Lygia Pepe e Só Resta o Cheiro de Marcelo Silveira, essa seleção figurará como síntese última da experiência e da intuição proporcionada por essa exposição. Recuperando o texto que a apresentava na X Bienal do Mercosul (2015) a Olfatória consiste numa exposição que privilegia manifestações contemporâneas na arte com caráter antioculares, buscando produzir uma reflexão sobre os outros sentidos. "O cheiro como uma plataforma interpretativa capaz de propiciar a legibilidade no processo de recepção das obras” (X Bienal do Mercosul 2015). De certo modo, quando um sentido é ativado os outros podem ser também acionados, assim como os seus significados e tais sentidos acionados podem despertar, produzir. Penso que essas obras falam disto. 
A possibilidade de compor paisagens olfativas traz consigo a evocação de imagens na consciência, como a obra Antes Que Eu Te Engula Carrocell Flower, (ver figura 13) uma espécie de "medusa" feita de elastano, lembrando o tecido das meias finas em sua coloração transparente; o artista denomina o material de tulha de elastano com madeira e temperos. Essa é uma obra que se pode adentrar como uma paisagem, os cheiros predominantes eram a canela, o curry, o açafrão. Temperos pungentes cujo o reconhecimento são evocadores de memórias e de sabores. Desse modo, mais de um sentido pode ser acionado provocando uma relação sinestésica. Cada sujeito comporá, junto com tal obra, todas lembranças que esses cheiros e, por consequência, sabores podem provocar, cada qual pode ter sua própria galeria íntima debaixo da tulha, galeria de sentimentos e sensações que, de certo modo, trilhamos ao experimentar as obras da mostra, identificando diferentes perfumes e mesmo sabores nas instalações. Paisagens imaginárias são então criadas na fatal experiência dos espectadores. Mas haverá uma essência dessa experiência? Elos intersubjetivos que conectam essas paisagens íntimas?

A obra de Lygia Pepe Círculo dos Prazeres (ver figura 14) é formada por 16 tigelas e 16 pires com conta-gotas, cheias de líquido e cores vibrantes: o vermelho, o amarelo, o azul e o verde, cuja intenção é: não apenas sentir o odor, mas também experimentar as cores, de acordo com Borja-Villel (2017).

\section{Figura 14 - Círculo dos Prazeres, de Lygia Pepe}

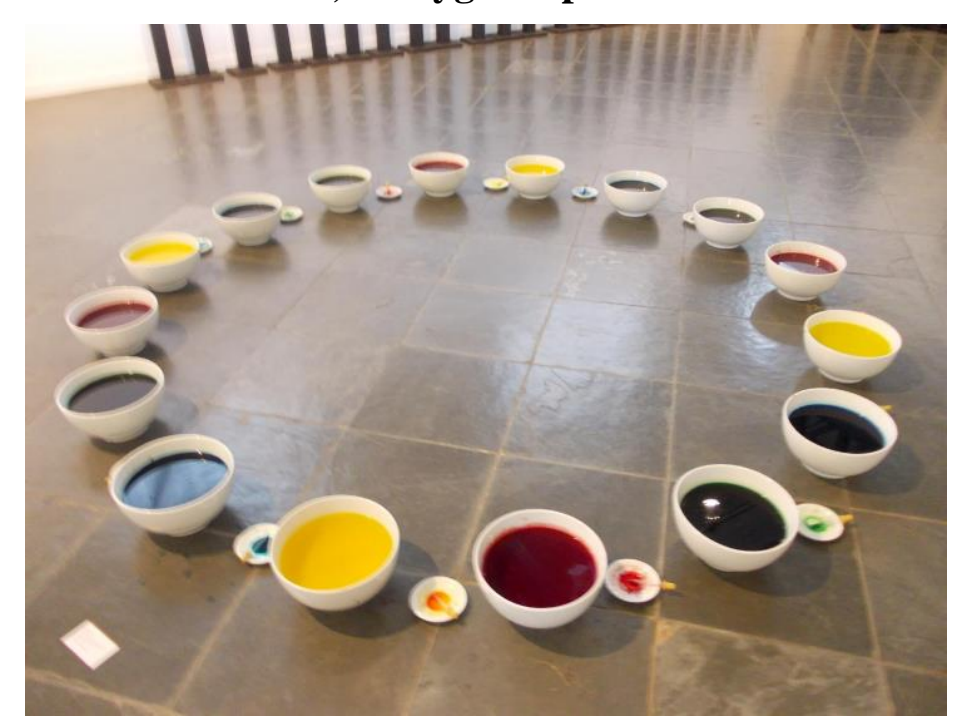

Exposição X Bienal do Mercosul, Espaço Usina do Gasômetro. Porto Alegre-RS 2015. Foto de Valéria Cristina P. da Silva.

Além da possibilidade poética de provar o sabor do azul, do vermelho do amarelo, sentir o odor das cores, o círculo ainda proporciona intensa visualidade a partir da forma. Não deixa de ser uma lúdica ciranda líquida sustentada por recipientes. 
O branco das tigelas acentua e destaca o líquido colorido. A soma dos prazeres é sinestésica sobretudo, os tons de amarelo e vermelho e olhando as tigelas podemos imaginar o sabor, experimentando-lhes o cheiro a aproximação é completa. Tomando o conta-gotas, bebemos a própria obra de arte. Não basta mais ver é preciso viver, essa é a paisagem inaugurada pela obra de arte contemporânea. Esse experimentar implica também em levar conosco o a obra, interioriza-la de outro modo que não apenas intelectual, racional. Quando provamos algo através dos nossos sentidos inaugura-se outra tonalidade emotiva.

\section{Figura 15 - Só Resta o Cheiro, de Marcelo Silveira (2005)}

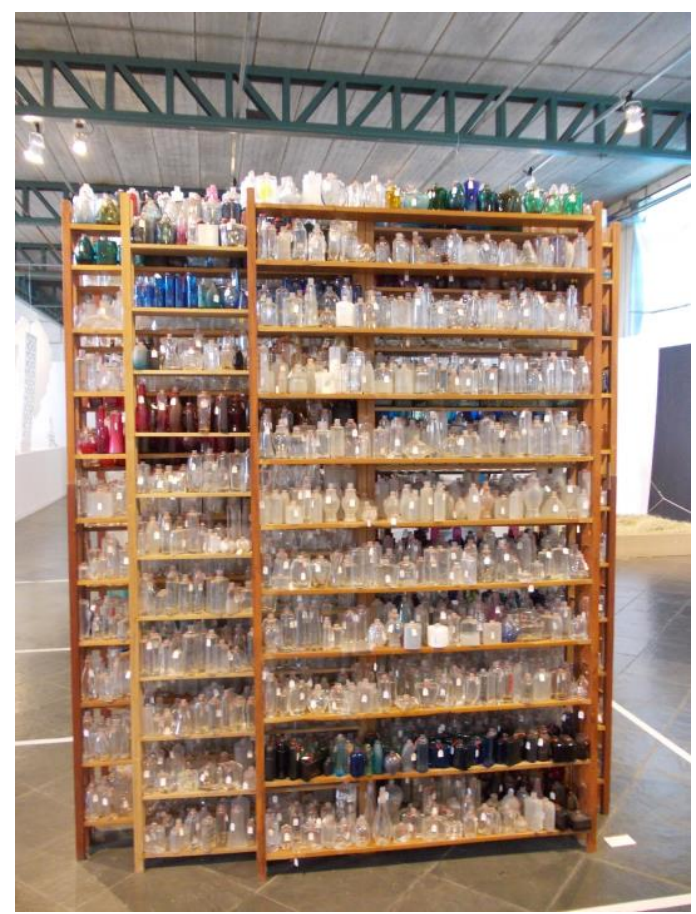

Exposição X Bienal do Mercosul, Espaço Usina do Gasômetro. Porto Alegre - RS, 2015. Foto de Valéria Cristina P. da Silva.

Por fim, a obra Só Resta o Cheiro - Marcelo Silveira é composta de cinco mil vidro de perfume vazios, enumerados e depositados em estantes de madeira (ver figura 15). Como o título da obra sugere o conteúdo evaporou, passando do líquido para o gasoso, fluiu mas deixou vestígios, uma essência passível de identificação. Os vidros são variados, também aglutinados por sua coloração, predominando os vidros transparentes. Jogando com uma ideia de visível do líquido através do vidro, sua translucidez e o invisível naquilo que não partiu totalmente, cheiro, e o que já não está mais, o etério da matéria líquida evaporada - o perfume faz - com que esse jogo de transparências e sentidos presentes e ausentes torne-se imaginário. A água solidificada é como vidro, os estados da matéria, o líquido, o sólido, o gasoso estão potencialmente 
co-presentes nessa obra. Estamos para essas obras, como estamos para paisagem, adentramos, compomos, sentimos, somos.

\section{CONSIDERAÇÕES FINAIS}

As palavras sensibilidade e sensível tem aparecido reiteradamente na produção acadêmica dos últimos anos, tanto em textos de autores nacionais como estrangeiros. Buscamos neste artigo apresentar a emergência da sensibilidade contemporânea a partir das artes visuais em suas imagens fluídas. Mas o que é sensibilidade nesta perspectiva contemporânea? Evidentemente, o modesto recorte aqui estabelecido não pode sublinhar todos os contornos do tema. A sensibilidade não deve ser confundida com sentimentalismo piegas, superficial. Sensibilidade, a priori, é tudo que se liga a percepção, a capacidade de apreender o mundo fora de uma lógica necessariamente racional e, ainda assim, dotá-la de sentido. A sensibilidade, então, como uma perspicácia cognoscitiva-afetiva começa pelos sentidos e a arte contemporânea tem milhares de estratégias para fazer sentir, para fazer perceber, utilizando a força própria dos sentidos. A sensibilidade como síntese da percepção, une-se a formação do imaginário e da memória e suas dinâmicas próprias, para articular-se com esses conteúdos. Podemos, então, pensar que sensibilidade e seus termos derivados: sensível, sensual constituem a capacidade de pinçar uma totalidade de sentido. A sensibilidade, enquanto perspicácia sensório-cognoscitiva que nos permite apreender o mundo, ajudando a conhecer, lembrar e imaginar. Quando chegamos num ponto razoável de articulação, o percebido, o lembrando pode atar-se a ação criativa e independente do imaginário.

A lição sobre a sensibilidade emergente que a poesia, enquanto poiesis, apresenta-nos através das artes é fazer sentir interligando, rompendo fronteiras entres os saberes: ciência, arte, filosofia, o imaginário da fluidez aqui explorado, por exemplo, pode ser encontrado em convergência nesses diferentes saberes e soma-se ao conteúdos sócio-culturais, espaciais e temporais contemporâneos. Compreender como os diferentes campos do pensamento, da ação, da cultura, da arte, da poesia intercruzam-se, corresponde também essa nova sensibilidade fluida, mutante operadora dos trânsitos entre a realidade a ficção, entre paisagem, poesia e lugar de sentido. No final, que tudo vire água: ondas, chuvas, águas-fortes, águas-furtadas e que esse precioso líquido vital possa por em marcha um límpido futuro. 


\section{REFERÊNCIAS}

ARANTES, Pedro Fiori. Arquitetura na era digital-Financeira: desenho, canteiro e renda da forma. São Paulo: Ed 34, 2012.

ARCHER, Michel. Arte contemporânea: uma história concisa. São Paulo: Martins Fontes, 2001.

BACHELARD, Gaston. O direito de sonhar. São Paulo: Difel, 1985.

A chama de uma vela. Rio de Janeiro: Bertrand Brasil, 1989.

A psicanálise do fogo. São Paulo: Martins Fontes, 2008a.

A água e os sonhos: ensaio sobre a imaginação da matéria. São Paulo: Martins Fontes, 1997.

A terra e os devaneios da vontade. São Paulo: Martins Fontes, 2008b.

A terra e os devaneios do repouso. São Paulo: Martins Fontes, 2003.

O ar e os sonhos. São Paulo: Martins Fontes, 2001.

poética do espaço. São Paulo: Martins Fontes, 1993.

A poética do devaneio. São Paulo: Martins Fontes, 1988.

A dialética da duração. São Paulo: Ática, 1994.

BAUMAN, Zygmunt. O mal estar na pós-modernidade. Rio de Janeiro: Jorge Zahar, 2001.

Tempos líquidos. Rio de Janeiro: Jorge Zahar, 2007.

BBC Brasil. Fotógrafo retrata paisagens turísticas pelo reflexo em bolhas. [s.1.]: 08 de setembro de 2011. Disponível em: <http://www.bbc.co.uk/portuguese/noticias/2011/09/110908_galeria_bolhas_rw.shtml>. Acesso em: 30 abr. 2013.

CALVINO, Ítalo. As cidades invisíveis. São Paulo: Cia das Letras, 1990.

Seis propostas para o próximo milênio. São Paulo: Cia das Letras, 1990.

CLAVAL, Paul. A paisagem dos geógrafos. In: CORRÊA, Roberto Lobato \& ROSENDHAL (org.). Geografia cultural: uma antologia. Rio de Janeiro: UERJ, 2012, p.245-276.

CONNOR, Steven. Cultura pós-moderna: introdução às teorias do contemporâneo. São Paulo: Edições Loyola, 1993.

COLLOT, Michel. Poética e filosofia da paisagem. Rio de Janeiro: Oficina Raquel, 
Valéria Cristina Pereira da Silva
Geografia, Literatura e Arte, v.1, n.1, p.94-123, jan./jun.2018

DOI: 10.11606/issn.2594-9632.geoliterart.2018.142143

2013.

CYPRIANO, Fabio. A biblioteca de Lygia Pape. Folha de São Paulo. São Paulo, 21 abr. 2001. Ilustrada, p. 13.

ESTADAO. Entrevista com Manoel Borja-Villel sobre a obra de Lygia Pape Disponível em: <http://cultura.estadao.com.br/noticias/geral,lygia-pape-la-fora-imp-,732437>. Acesso em: 6 nov. 2017.

FOLHA DE SÃO PAULO ILUSTRADA. A biblioteca de Lígia Pape. Disponível em: <http://www1.folha.uol.com.br/fsp/ilustrad/fq2104200113.htm>. Acesso em: 6 nov. 2017.

GUIMARÃES, Cao. O sopro. Disponível em: <http://www.caoguimaraes.com/obra/sopro/>. Acesso em: 8 nov. 2017.

LEMES, Daniel. Tom Storm fotografando o mundo em uma bolha. Disponível em: $<$ https://www.tutoriart.com.br/tom-storm-fotografando-o-mundo-em-uma-bolha/>. Acesso em: 8 nov. 2017.

MAFESOLI, Michel. A contemplação do mundo. Porto Alegre: Artes e Ofícios, 1995.

NARDINE, Bruno. Mitologia: primeiro encontro. São Paulo: Círculo do livro, 1982.

NAVES, Rodrigo. Mona Lisa no meio do redemoinho. In: Revista Novos Estudos. São Paulo: Centro Brasileiro de Análise e Planejamento (Cebrap), n. 67. nov. 2003. p. 143154. Acesso em: 15 mar. 2013. Disponível em <http://novosestudos.uol.com.br/indice/indice.asp?idEdicao=101>.

O INQUILINO. Direção de Cao Guimarães e Rivane Neuenschwander. Brasil, 2010. 10 min, digital, son., color.

PALHARES, Taisa. Texto de apresentação da exposição "Warm White" de Laura Vince. São Paulo: Pinacoteca do Estado de São Paulo, 2008.

PEIXOTO, Nelson Brissac. Paisagens urbanas. São Paulo: Senac, 2003.

PROUST, Marcel. Em busca do tempo perdido: A prisioneira. Rio de Janeiro: Nova Fronteira, 2016. vol. 3.

TELLES, Lygia Fagundes. A estrutura da bolha de sabão. Rio de Janeiro: Rocco, 1999.

SEVCENKO, Nicolau. História da vida privada no Brasil, São Paulo: Cia das letras, 1998. p. 513-619.

SILVA, Armando Correia da. A pós-vanguarda e a epistemologia do lugar. São Paulo: 1996, mimeo.

SOPRO. Direção de Cao Guimarães e Rivane Neuenschwander. Brasil, 2000. 5 min, digital, son., p/b. 
VIDICA, Ana Rita. Trânsitos entre fotografia e cinema: a partir das relações entre produção e recepção das obras artísticas. In: CICLO DE WORKSHOPS E PALESTRAS FOTOGRAFIA \& CINEMA. Goiânia, Vila Cultural, 29 set - 14 out. 2017.

X BIENAL DO MERCOSUL. Mensagem de uma nova América. Porto Alegre, 2015.

Recebido em 08/11/2017.

Aceito em 05/12/2017.

Publicado em 02/01/2018. 